J. Clin. Chem. Clin. Biochem.

Vol. 27, 1989, pp. 857-862

(C) 1989 Walter de Gruyter \& Co. Berlin - New York

\title{
Mutations in Acute Intermittent Porphyria Detected by ELISA Measurement of Porphobilinogen Deaminase
}

\author{
By L. Lannfelt, L. Wetterberg \\ Karolinska Institutet, Psykiatriska kliniken, S:ı Görans sjukhus, Stockholm \\ P. Gellerfors
}

Kabi, Lindhagensgatan 133, Stockholm

Lena Lilius, Ylva Floderus and S. Thunell

Klinisk kemiska laboratoriet, S:t Görans sjukhus, Stockholm

(Received May 23/July 19, 1989)

Summary: To study the existence of different mutations in acute intermittent porphyria, erythrocyte porphobilinogen deaminase activity and enzyme protein concentration were investigated in 125 porphyria gene carriers from 31 families, and in 121 apparently healthy controls. Porphobilinogen deaminase concentration $(\mu \mathrm{g} / \mathrm{gHb})$ was quantified using a recently developed double-sandwich ELISA. The ratio of enzyme catalytic activity to the concentration of enzyme protein was expressed as the porphobilinogen specific activity (nkat/g). The controls had a mean porphobilinogen deaminase concentration of $160 \pm 35 \mu \mathrm{g} / \mathrm{gHb}$ and a specific activity of $762 \pm 127 \mathrm{nkat} / \mathrm{g}$. Two different types of mutation causing acute intermittent porphyria were detected. The majority $(91 \%)$ of gene carriers, from 25 families, had a diminished porphobilinogen deaminase concentration of $102 \pm 18 \mu \mathrm{g} / \mathrm{gHb}$, with a slightly lowered specific activity of $634 \pm 105 \mathrm{nkat} / \mathrm{g}$. In $9 \%$ of the gene carriers, representing six different families, an increase in porphobilinogen deaminase concentration to $269 \pm 46$ $\mu \mathrm{g} / \mathrm{gHb}$, and a highly significant reduction in specific activity to $234 \pm 48 \mathrm{nkat} / \mathrm{g}$, were found, which indicates the presence of a different mutation.

\section{Introduction}

Acute intermittent porphyria is a dominantly inherited (1) inborn error of haem biosynthesis characteriżed by abdominal and neuropsychiatric symptoms $(2,3)$. The gene carrier state is often asymptomatic. Certain drugs, hormones, steroids, infections and starvation may precipitate acute attacks of the disease. Hepatic 5-aminolaevulinic acid synthase activity is induced and an increased urinary excretion of 5-aminolaevulinic acid and porphobilinogen occur. Heterozygotes for the acute intermittent porphyria gene

\footnotetext{
1) Enzyme

Porphobilinogen deaminase (syn: uroporphyrinogen-I-synthetase, hydroxymethylbilane synthetase) EC 4.3.1.8
}

have a reduced activity of porphobilinogen deaminase ${ }^{1}$ ). Measurement of the erythrocyte activity of the enzyme has proved to be a valuable tool in the detection of latent carriers of the disease. However, there exists an overlap zone of enzyme activity, where both acute intermittent porphyria gene carriers and non-carriers are found (4-9).

The porphobilinogen deaminase gene has been cloned (10) and shown to code for two enzymes $(11,12)$. One form $\left(M_{\mathrm{r}} 42000\right)$ is found exclusively in erythopoietic tissue, and an extended version $\left(M_{\mathrm{r}} 44000\right)$ is present in non-erythropoietic cells. The cloned gene has been used for restriction fragment length polymorphism studies $(13,14)$, and in informative families 
this approach has been of diagnostic value. Porphobilinogen deaminase has been purified and monospecific polyclonal anitbodies against the enzyme have been produced in rabbits $(15-19)$. Different classes of enzyme defect have been identified from the amount of immunologically cross-reacting enzyme material (CRIM) in erythrocyte lysates of acute intermittent porphyria heterozygotes. Four classes of mutation were identified with the use of rocket immunoelectrophoresis (15-17), two CRIM-negative and two CRIM-positive. The majority of CRIMnegative families, designated type 1 , exhibited halfnormal porphobilinogen deaminase activity, which was accounted for by a reduction of porphobilinogen deaminase protein. Some families had a normal erythrocyte enzyme activity (20) and were designated CRIM-negative type 2. Other families had CRIMpositive mutations. One type had moderately elevated concentrations of porphobilinogen deaminase protein in erythrocyte lysate and was designated CRIM-positive type 1 . The other CRIM-positive mutation, type 2 , had markèdly more enzyme protein. In the present study a Swedish collective of acute intermittent porphyria heterozygotes and normal controls was investigated for erythrocyte porphobilinogen deaminase activity, porphobilinogen deaminase protein concentration measured by ELISA (21) and porphobilinogen deaminase specific activity, i.e. enzyme activity related to the concentration of enzyme protein.

\section{Materials, Methods and Human Subjects}

\section{Materials}

Microtitre plates and an Immunowash 8 were obtained from Nunc (Roskilde, Denmark). ELISA absorbances were read in a MR 700 Microplate reader, Dynatech Laboratories (Guernsey, Great Britain). Evacuated heparinized test tubes were purchased from Becton-Dickinson (Plymouth, Great Britain).

\section{Porphobilinogen deaminase activity}

The activity of porphobilinogen deaminase in erythrocyte lysate was measured according to the method of Magnussen et al. (22). The enzyme activity was expressed in two ways: picokatal per gram haemoglobin (pkat/g Hb) and nanokatal per litre red blood cells (nkat/l). The latter method of calculation was employed in the original publication, and it is used again here to facilitate comparison with earlier reports and earlier investigations in our laboratory.

\section{The ELISA}

A monospecific polyclonal antiserum was raised in rabbits against the erythropoietic form of porphobilinogen deaminase, purified from human red blood cells (23). For immunological quantification of porphobilinogen deaminase enzyme protein in human erythrocyte lysate, a double-sandwich enzyme-linked immunosorbent assay (ELISA) was developed (21). The IgG fraction used was shown to be monospecific by immunoblot- ting, rocket immunoelectrophoresis and immunotitration. A measuring range from $4 \mathrm{ng}$ to $50 \mathrm{pg}$ was demonstrated. Intraand inter-assay coefficients of variation were $6 \%$ and $7 \%$ respectively.

Lysis of the erythrocytes was achieved by freezing at $-20^{\circ} \mathrm{C}$ and thawing. Prior to analysis, $25 \mu \mathrm{l}$ of the lysate was diluted

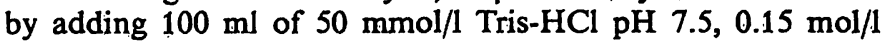
$\mathrm{NaCl}$. One hundred $\mu \mathrm{l}$ of the 1:4000 dilution was added to each of the microtitre plate wells. Duplicate samples were used. Erythrocyte lysate from a patient with a high concentration of porphobilinogen deaminase, as determined by titration against the purified enzyme, was used as an internal standard and included in each assay. Haemoglobin concentration was measured in the diluted erythrocyte lysate samples in the MR 700 Microplate reader as the absorbance at $410 \mathrm{~nm}$. Assay results were expressed as microgram porphobilinogen deaminase enzyme protein per gram haemoglobin $(\mu \mathrm{g} / \mathrm{g} \mathrm{Hb})$.

\section{Specific activity}

The porphobilinogen deaminase specific activity was determined in erythrocyte lysates from controls and acute intermittent porphyria by dividing the porphobilinogen deaminase activity (pkat/g Hb) by the porphobilinogen deaminase protein concentration $(\mu \mathrm{g} / \mathrm{g} \mathrm{Hb})$ as measured by ELISA. The specific activity was expressed as nanokatal per gram porphobilinogen deaminase enzyme protein (nkat/g).

\section{Human subjects}

Carriers of the acute intermittent porphyria gene, 125 individuals from 31 different families, were investigated. According to genealogical data, 68 of the carriers were descended from the large family from northern Sweden first described by Waldenström $(1,24)$. The diagnosis of acute intermittent porphyria was documented by a careful investigation of biochemical findings, family history of acute intermittent porphyria and clinical symptoms. Eighty nine of the 125 acute intermittent porphyria gene carriers were investigated for 5-aminolaevulinate and porphobilinogen in the urine. Excess excretion was found in 82 of them and in seven a normal amount of 5-aminolaevulinate and porphobilinogen was found. The other 36 acute intermittent porphyria gene carriers were diagnosed only by porphobilinogen deaminase activity. There was no statistically significant difference in porphobilinogen deaminase activity between these groups (unpaired t-test, $\mathrm{p}<0.001$ ). As controls, 121 apparently healthy individuals of matching age and sex were used.

\section{Blood samples}

Heparinized blood was collected by venous puncture and sent by post to the laboratory. After centrifugation at $2000 \mathrm{~g}$ for 10 minutes at room temperature, the plasma was carefully removed. The erythrocytes were stored at $-20^{\circ} \mathrm{C}$ up to six months before assay. Storage within this period of time did not affect the assay results.

\section{Results}

Erythrocyte porphobilinogen deaminase activity

Figures $1 \mathrm{a}$ und $\mathrm{b}$ show the erythrocyte porphobilinogen deaminase activity in control persons and in acute intermittent porphyria heterozygotes, exprèssed as pkat/g Hb and nkat/l. The erythrocyte porphobilinơgen deaminase activity was $120 \pm 26$ pkat/g $\mathrm{Hb}$ 


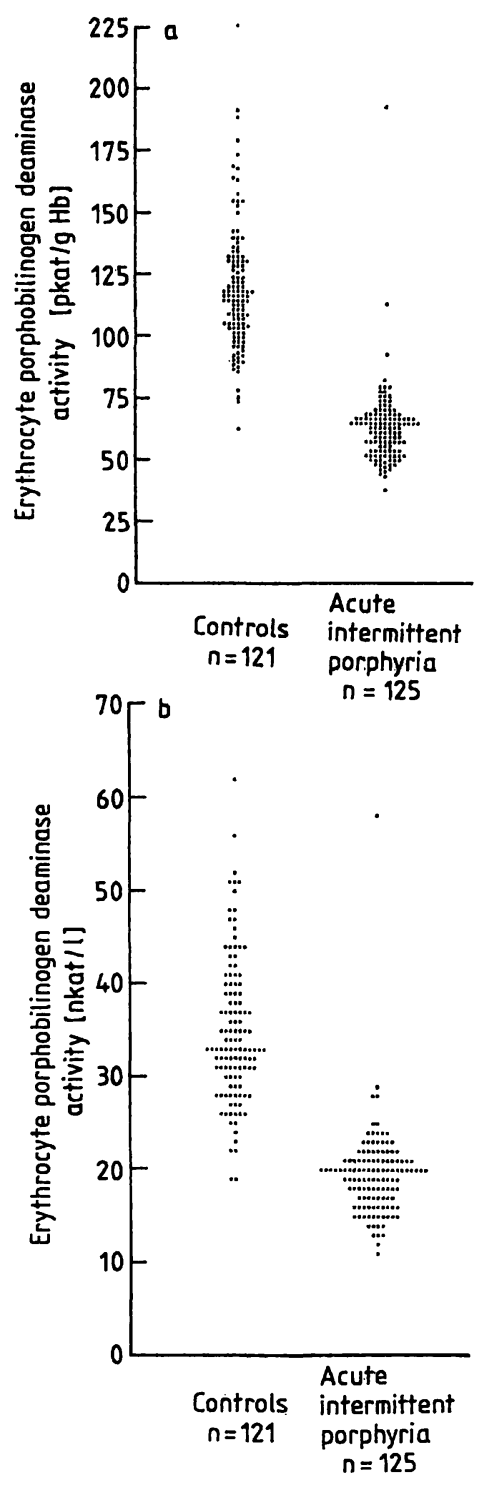

Fig. 1. Erythrocyte porphobilinogen deaminase enzyme activity in acute intermittent porphyria heterozygotes and in controls, enzyme activity expressed as pkat/g Hb (a) and nkat/l (b). One point represents one individual.
(36 \pm 8 nkat/l) for the controls and $65 \pm 16$ pkat/g $\mathrm{Hb}(20 \pm 5 \mathrm{nkat} / \mathrm{l})$ for the acute intermittent porphyria gene carriers. A considerable overlap in activity between controls and patients is noted, in agreement with previous reports (4-9). At the time of the investigation one of the acute intermittent porphyria heterozygotes had a metastatic carcinoma of the prostate and severe anaemia with a haemoglobin concentration of $70 \mathrm{~g} / \mathrm{l}$. This patient exhibited a substantially increased porphobilinogen deaminase activity of 189 pkat/g Hb (58 nkat/l), (tab. 1), which is more than $+3 \mathrm{SD}$ outside the mean for the remaining patients in the group. Three years earlier, when the patient had a normal haemoglobin concentration, his erythrocyte porphobilinogen deaminase activity was 20 nkat $/ 1$.

Erythrocyte porphobilinogen deaminase enzyme protein concentration

Figure 2 shows the porphobilinogen deaminase enzyme protein concentration in controls and acute intermittent porphyria heterozygotes. The controls had a porphobilinogen deaminase concentration of $160 \pm 35 \mu \mathrm{g} / \mathrm{gHb}$. The acute intermittent porphyria heterozygotes fell into two distinct groups. More than $90 \%$ of the patients $(\mathrm{n}=113)$ from 25 different families, exhibited a lower concentration $(102 \pm 18 \mu \mathrm{g} / \mathrm{g}$ $\mathrm{Hb}$ ), compared with the controls, which indicates a CRIM-negative mutation. However, 12 acute intermittent porphyria heterozygotes $(9 \%)$ from six different families, had a markedly raised concentration of $277 \pm 52 \mu \mathrm{g} / \mathrm{g} \mathrm{Hb}$, which signifies a CRIM-positive mutation.

Tab. 1. Erythrocyte porphobilinogen deaminase (PBGD) activity, enzyme protein concentration and specific activity in 121 controls and 125 acute intermittent porphyria heterozygotes.

\begin{tabular}{|c|c|c|c|c|c|c|c|c|c|c|c|c|}
\hline & \multicolumn{3}{|c|}{$\begin{array}{l}\text { Controls } \\
\mathrm{n} \equiv 121 \\
\end{array}$} & \multicolumn{3}{|c|}{$\begin{array}{l}\text { Acute intermittent } \\
\text { porphyria } \\
\mathrm{n}=125\end{array}$} & \multicolumn{3}{|c|}{$\begin{array}{l}\text { Acute intermittent } \\
\text { porphyria } \\
\text { CRIM negative, } n=113\end{array}$} & \multicolumn{3}{|c|}{$\begin{array}{l}\text { Acute intermittent } \\
\text { porphyria } \\
\text { CRIM positive, } n=11^{a} \text { ) }\end{array}$} \\
\hline & Mean & S.D. & Range & Mean & S.D. & Range & Mean & S.D. & Range & Mean & S.D. & Range \\
\hline $\begin{array}{l}\text { PBGD activity } \\
\text { (pkat/g Hb) }\end{array}$ & 120 & 26 & $63-225$ & 65 & 16 & $38-189$ & 64 & 11 & $38-114$ & 61 & 6 & $52-69$ \\
\hline $\begin{array}{l}\text { PBGD activity } \\
\text { (rikat/l) }\end{array}$ & 36 & 8 & $19=70$ & 20 & 5 & $11-58$ & 20 & 3 & $11-30$ & 19 & 2 & $16-24$ \\
\hline $\begin{array}{l}\text { PBGD } \\
\text { concentration } \\
(\mu \mathrm{g} / \mathrm{g} \mathrm{Hb})\end{array}$ & 160 & 35 & $102-268$ & 119 & 57 & $63-363$ & 102 & 18 & $63-148$ & 269 & 46 & $210-344$ \\
\hline $\begin{array}{l}\text { PBGD specific } \\
\text { activity } \\
\text { (nkat/g) }\end{array}$ & 762 & 127 & $522-1189$ & 600 & 149 & $170-950$ & 634 & 105 & $430-950$ & 234 & 48 & $171-320$ \\
\hline
\end{tabular}

a) One CRIM-positive patient was excluded (see Discussion), with a porphobilinogen deaminase activity of $189 \mathrm{pkat} / \mathrm{gHb}$ (58 nkat/l), a porphobilinogen deaminase concentration of $363 . \mu \mathrm{g} / \mathrm{g} \mathrm{Hb}$ and a porphobilinogen deaminase specific activity of 520 nkat/g. 


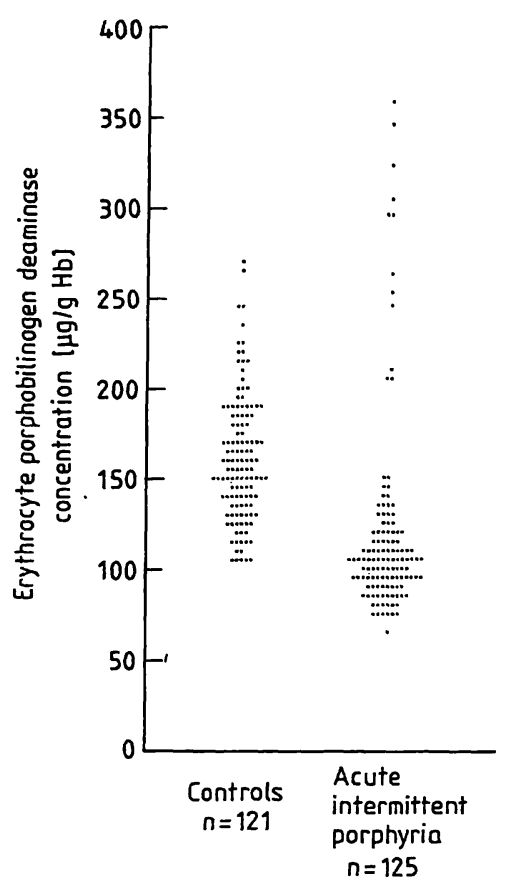

Fig. 2. Concentration of immunologically detectable porphobilinogen deaminase protein in erythrocyte lysates in acute intermittent porphyria heterozygotes and in controls, measured by ELISA.

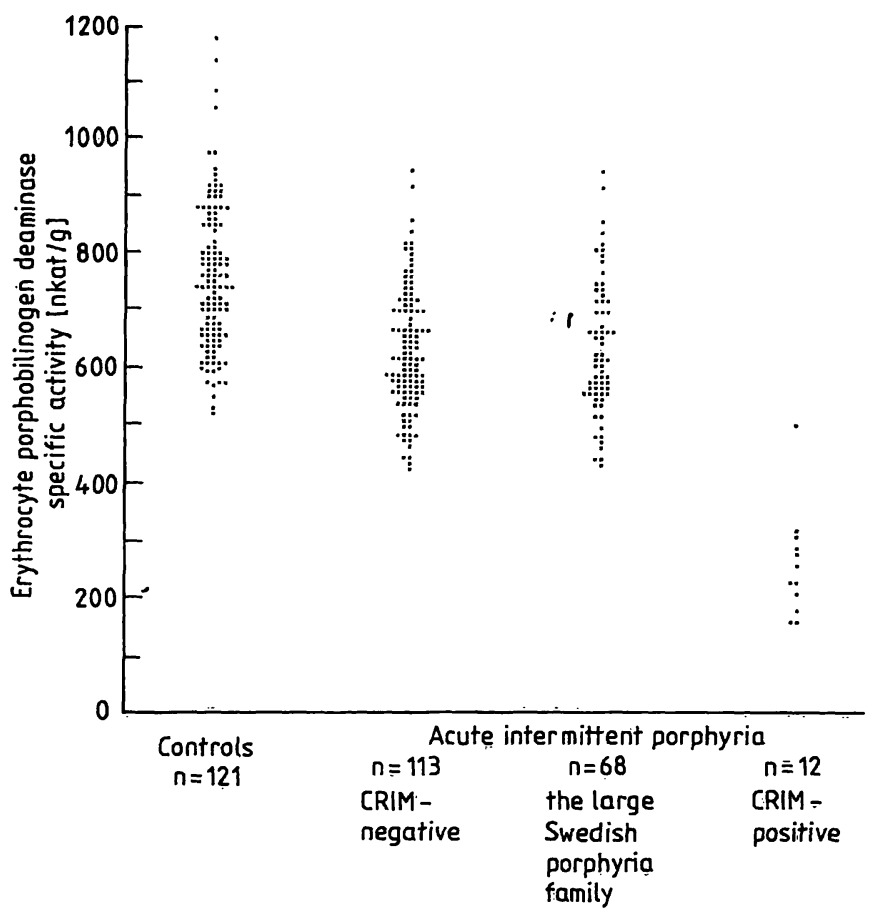

Fig. 3. Erythrocyte porphobilinogen deaminase specific activity in controls and in CRIM-negative and CRIM-positive acute intermittent porphyria heterozygotes. Individuals belonging to the same CRIM-negative family from northern Sweden are plotted separately. CRIM = immunologically cross-reacting enzyme material

tein concentration in erythrocyte lysates. In the present work it was applied in the study of a population of Swedish acute intermittent porphyria gene carriers. Two classes of mutations were revealed, one CRIMnegative with a low concentration of porphobilinogen deaminase enzyme protein and one CRIM-positive with a high porphobilinogen deaminase concentration, compared with controls. The CRIM-positive carriers exhibited a highly significant reduction in porphobilinogen deaminase specific activity, which indicates that immunoreactive non-catalytic enzyme protein encoded by the mutant allele was detected by the ELISA. The CRIM-positive carriers also had a considerable increase of catalytically inactive protein and are probably of a type similar to the CRIMpositive type 2 classs, previously described (17), which may be caused by a mutation in the structural gene. However, the CRIM-negative acute intermittent porphyria heterozygotes also had a significantly lowered porphobilinogen deaminase specific activity, although not of the same magnitude as the CRIM-positive group. In a pure regulatory gene defect the mutant allele is not considered to produce an enzymic with diminished activity. The CRIM-negative mutation(s) may thus represent changes in the DNA, leading to altered enzyme stability, mRNA transcription or prócessing. 


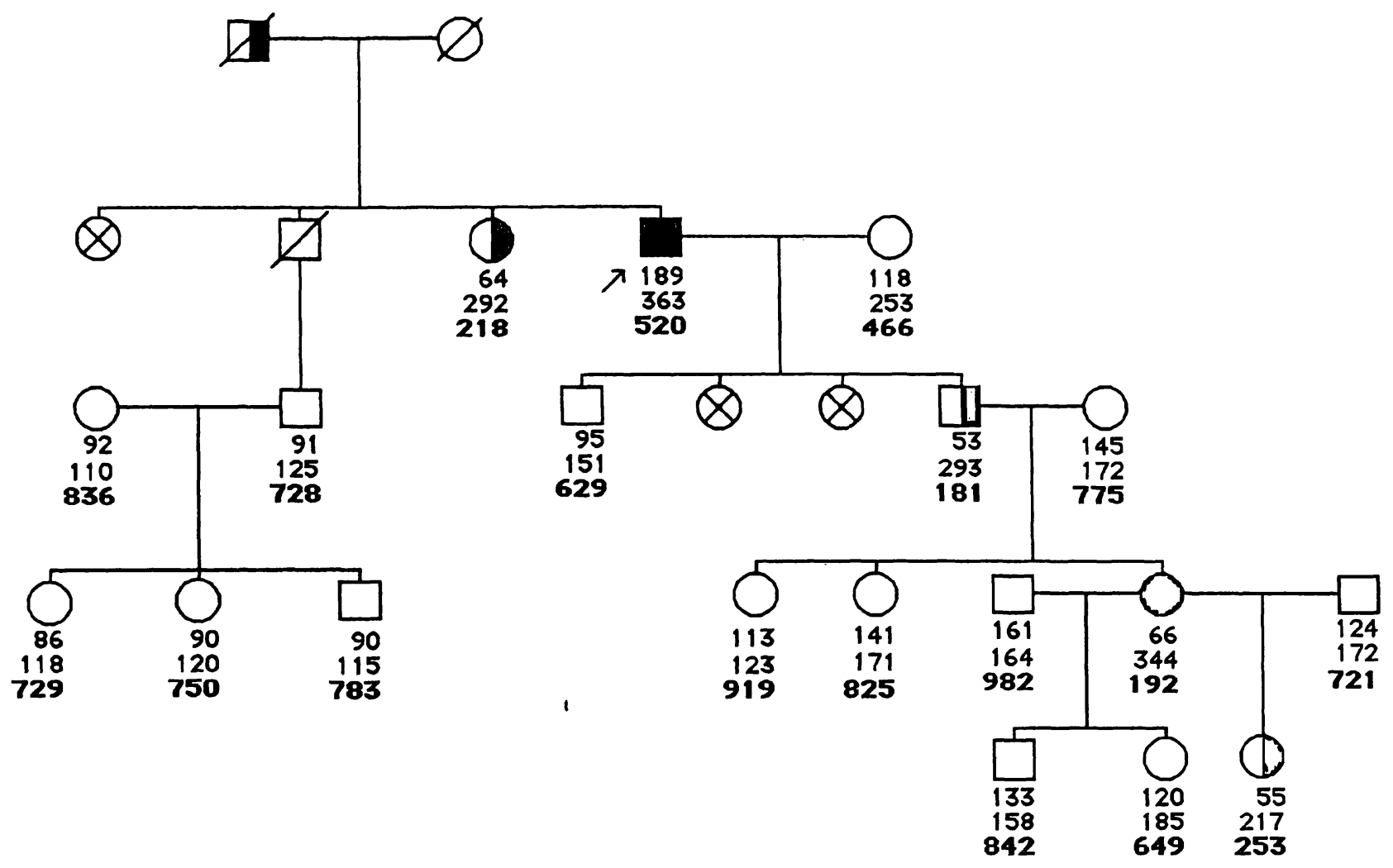

Fig. 4. A CRIM-positive acute intermittent porphyria family. Figures under symbols denote values obtained for porphobilinogen deaminase activity expressed as pkat/g Hb (upper), porphobilinogen deaminase concentration expressed as $\mu \mathrm{g} / \mathrm{g} \mathrm{Hb}$ (middle) and, in bold type, the porphobilinogen deaminase specific activity expressed as nkat/g (lower).

(1) deceased acute intermittent phorphyria heterozygote

O, $\square \quad$ unaffected

- acute intermittent porphyria heterozygote with clinically manifest disease

$\otimes \quad$ not investigated

D, D asymptomatic acute intermittent porphyria heterozygote

a proband with anaemia and metastatic cancer of the prostate

In the CRIM-positive family presented in figure 4, the inheritance of the mutation was clearly demonstrated, as all gene carriers showed an increased porphobilinogen deaminase concentration. All carriers also showed a decreased porphobilinogen deaminase specific activity, except the proband with anaemia and metastatic cancer of the prostate, who fell more than $+3 \mathrm{SD}$ outside the group in this respect. He had a porphobilinogen deaminase concentration of the same magnitude as the other gene carriers in the family but considerably raised enzyme activity, which explains the increase in porphobilinogen deaminase specific activity to 520 nkat/g. Statistically he was not representative of the CRIM-positive group. It has been reported that the porphobilinogen deaminase enzyme activity in red blood cells is also subject to regulation by factors other than the major gene on chromosome 11 (25). It has further been shown that porphobilinogen deaminase activity may be increased in haemolytic disorders, in liver cirrhosis and other liver affections and in malignancies (26-28).

By measuring porphobilinogen deaminase protein concentration in addition to porphobilinogen deami- nase activity, different mutations of acute intermittent porphyria can be distinguished. The information gained may be of diagnostic value, since in CRIMpositive families the raised porphobilinogen deaminase enzyme protein concentration and the decreased porphobilinogen deaminase specific activity distinguish between carriers and non-carriers of the gene defect. In CRIM-negative mutations, the porphobilinogen deaminase enzyme protein quantification yields additional information on the erythrocyte enzyme. The diagnostic potential of this information will be further evaluated. However, the ELISA method now available is less time-consuming than the traditional enzyme activity assay. It therefore offers a new means of rapidly investigating a large number of samples from populations at risk for the disease.

\section{Acknowledgement}

The authors wish to thank Lotta Forsell for skilled technical assistance and Anna-Lisa Mouchard at the Swedish Porphyric Association for help in organizing the genealogical data.

This investigation was supported by the Swedish Medical Rcsearch Council (project 13X-7483) and the Professor Gadelius Memorial Foundation. 


\section{References}

1. Waldenström, J. (1937) Studien über Porphyrie. Acta Med. Scand., Suppl. 82.

2. Wetterberg, L. (1967) A neuropsychiatric and genetical investigation of acute intermittent porphyria. Svenska bokförlaget/Norstedts, Stockholm.

3. Kappas, A., Sassa, S. \& Anderson, K. E. (1983) The porphyrias. In: The Metabolic Basis of Inherited Disease (Stanbury, J. B., Wyngaarden, J. B., Frederickson, D. S., Goldstein, J. L. \& Brown, M. S., eds.) pp. 1301-1384, MacGraw-Hill Inc., New York.

4. Astrup, E. G. (1978) Family studies on the activity of uroporphyrinogen-I-synthase in diagnosis of acute intermittent porphyria. Clin. Sci. Mol. Med. 54, 251-256.

5. Bottomley, S. S., Bonkowsky, H. L. \& Kreimer-Birnbaum, M. (1981) The diagnosis of acute intermittent porphyria. Usefulness and limitations of the erythrocyte uroporphyrinogen-I-synthase assay. Am. J. Clin. Pathol. 6, 133-139.

6. Lamon, J. M., Frykholm, B. C. \& Tschudy, D. P. (1979) Family evaluations in acute intermittent porphyria using red cell uroporphyrinogen-1-synthetase. J. Med. Gen. 16, 134-139.

7. Pierach, C. A., Weimer, M. K., Cardinal, R. A., Bossenmaier, I. C. \& Bloomer, J. R. (1987) Red blood cell porphobilinogen deaminase in the evaluation of acute intermittent porphyria. J. Am. Med. Ass. 257, 60-61.

8. Bonaiti-Pellié, C., Phung, L. \& Nordmann, Y. (1984) Recurrence risk estimation of acute intermittent porphyria based on analysis of porphobilinogen deaminase activity: A Bayesian approach. Am. J. Med. Genet. 19, 755-762.

9. Thunell, S. (1986) Diagnosis of disturbances of porphyrin metabolism. Läkartidningen 83, 3242-3245, 3248-3251.

10. Raich, N., Romeo, P. H., Dubart, A., Beaupain, D., CohenSolal, M. \& Goossens, M. (1986) Molecular cloning and complete primary sequence of human erythrocyte porphobilinogen deaminase. Nucleic Acids Res. 14, 59555968.

11. Grandchamp, B., de Verneuil, H., Beaumont, C., Chretien, S., Walter, O. \& Nordmann, Y. (1987) Tissue-specific expression of porphobilinogen deaminase. Two isoenzymes from a single gene. Eur. J. Biochem. 162, 105-110.

12. Chretien, S., Dubart, A., Beaupain, D., Raich, N., Grandchamp, B., Rosa, J., Goossens, M. \& Romeo, P. H. (1988) Alternative transcription and splicing of the human porphobilinogen deaminase gene result either in tissue-specific or in housekeeping expression. Proc. Natl. Acad. Sci. USA $85,6-10$.

13. Llewellyn, D. H. Kalsheker, N. A., Harrison, P. R., Picat, C., Romeo, P. H., Elder, G. H., Marsh, O. W. M., Grandchamp, B., Nordmann, Y. \& Goossens, M. (1987) A Msp I polymorphism for the human porphobilinogen deaminase gene. Lancet $i, 706-708$.

14. Lee, J.-S., Anvret, M., Lindsten, J., Lannfelt, L., Gellerfors, P., Wetterberg, L., Floderus, Y. \& Thunell, S. (1988) DNA polymorphisms within the porphobilinogen deaminase gene in two Swedish families with acute intermittent porphyria Hum. Genet. 79, 379-381.
15. Anderson, P. M., Reddy, R. M., Anderson, K. E. \& Desnick, R. J. (1981) Characterization of the porphobilinogen deaminase deficiency in acute intermittent porphyria. J. Clin. Invest. 68, 1-12.

16. Desnick, R. J., Ostasiewicz, L. T., Tishler, P. A. \& Mustajoki, P. (1985) Acute intermittent porphyria: Characterization of a novel mutation in the structural gene for porphobilinogen deaminase. J. Clin. Ińlest. 76, 865-874.

17. Mustajoki, P. \& Desnick, R. J. (1985) Genetic heterogeneity in acute intermittent porphyria: characterization and frequency of porphobilinogen deaminase mutations in Finland. Brit. Med. J. 291, 505-509.

18. de Rooij, F. W. M., Hamer, C. M. \& Wilson, J. H. P. (1987) Purification of porphobilinogen deaminase from human erythrocytes by fast protein liquid chromatography. Clin. Chim. Acta $162,61-68$.

19. Nunn, A. V. W., Gardner, L. C. \& Cox, T. M. (1987) Molecular forms of porphobilinogen deaminase in acute intermittent porphyria. A study by Western immunoblotting. Quart. J. Med. 64, 589-599.

20. Mustajoki, P. (1981) Normal erythrocyte uroporphyrinogen I synthase in a kindred with acute intermittent porphyria. Ann. Intern. Med. 95, 162-166.

21. Lannfelt, L., Wetterberg, L., Lilius, L., Thunell, S. \& Gellerfors, P. (1989) ELISA for measuring porphobilinogen deaminase in human erythrocytes. Clin. Chim. Acta 183, 223-238.

22. Magnussen, C. R., Levinè, J. B., Doherty, J. M., Cheesman, J. O. \& Tschudy, D. P. (1974) A red cell enzyme method for the diagnosis of acute intermittent porphyria. Blood 44, $857-858$.

23. Lannfelt, L., Wetterberg, L., Lilius, L., Thunell, S., Jörnvall, H., Pavlu, B., Wielburski, A. \& Gellerfors, P. (1989) Porphobilinogen deaminase in human erythrocytes; Purification of two forms with apparent molecular weights of $40 \mathrm{kDa}$ and $42 \mathrm{kDa}$. Scand. J. Clin. Lab. Invest., in press.

24. Waldenström, J. (1982) Geography and genetics of the porphyrias. Acta Derm. Venereol. 100, 43-46.

25. Wetterberg, L., Floderus, Y., Thunell, S., Iselius, L. \& Lindsten, J. (1983) Genetic regulation of the red cell uroporphyrinogen-I-synthetase level in families with acute intermittent porphyria. Clin. Genet. 24, 403-406.

26. Anderson, K. E., Sassa, S., Peterson, C. M. \& Kappas, A. (1977) Increased erythrocyte uroporphyrinogen-I-synthetase, delta-aminolevulinic acid dehydratase and protoporphyrin in hemolytic anemias. Am. J. Med. 63, 359-364.

27. Blum, M., Koel, C. \& Abecassis, J. (1978) Variations in erythrocyte uroporphyrinogen I synthetase activity in nonporphyrias. Clin. Chim. Acta 87, 119-125.

28. Epstein, O., Lahav, M., Schoenfeld, N., Shaklai, M. \& Atsmon, A. (1983) Erythrocyte uroporphyrinogen syrithase activity as a possible diagnostic aid in the diagnosis of lymphoproliferative diseases. Cancer $52,828-832$.

Dr Lars Lannfelt

Karolinska Institute

Department of Psychiatry

St. Göran's Hospital

Box 12500

S-11281 Stockholm 